\title{
3 Research Square \\ Risk of primary lung cancer after breast cancer radiotherapy: A systematic review and meta-analysis
}

\section{Bushra Zareie}

Hamadan University of Medical Sciences

Mohammad Aziz Rasouli

Kurdistan University of Medical Science: Kurdistan University of Medical Sciences

Jalal Poorolajal (D poorolajal@yahoo.com)

Hamadan University of Medical Sciences

\section{Research article}

Keywords: Breast neoplasms, Radiotherapy, Lung neoplasms, Small cell lung carcinoma

Posted Date: April 20th, 2021

DOI: https://doi.org/10.21203/rs.3.rs-419176/v1

License: @ (i) This work is licensed under a Creative Commons Attribution 4.0 International License. Read Full License 


\section{Abstract}

Background: Epidemiological studies have shown that the risk of secondary malignancies may increase by radiotherapy. Lung cancer is the most important long-term complication of breast cancer radiotherapy.

Methods: Major electronic databases including Scopus, Web of Science, and MEDLINE were searched. All cohort studies that investigated the association between radiotherapy for breast cancer and risk of primary lung, bronchus and trachea cancers conducted until March 2021 were included. The study participants were evaluated regardless of their age and ethnicity. The Newcastle-Ottawa Scale was used to assess the quality of the studies. The designated effects were risk ratio (RR). The random-effects model was used to estimate the average effects.

Results: Fifteen studies including 1,640,247 women with primary breast cancer were identified of which 937,151 had not received radiotherapy and 703,096 subjects had received radiotherapy. In general, there was no significant association between breast cancer radiotherapy and lung cancer based on 10 studies (RR $=0.95$, $95 \% \mathrm{Cl}: 0.87-1.02, \mathrm{P}=0.15)$, There was no association between breast cancer radiotherapy and lung, bronchus, and trachea cancers either based on 5 studies ( $R R=0.98,95 \% \mathrm{Cl}$ : 0.93-1.02, $\mathrm{P}=0.32$ ).

Conclusion: Radiotherapy for breast cancer is not associated with an excess risk of lung cancer. Due to the limited number of studies, further research about lung doses from breast cancer radiotherapy varied substantially worldwide, is suggested to the risk of lung cancer after breast cancer radiotherapy.

\section{Introduction}

Randomized clinical trial studies have shown that radiotherapy significantly reduces breast cancer recurrence. On average, it can reduce breast cancer mortality by a few percent depending on the characteristics of cancer. The benefits of radiotherapy are greater than the long-term complications for patients with breast cancer $(1-4)$.

During radiotherapy for the breast and chest wall, the lungs are exposed to radiation, which is unavoidable. This accidental exposure may increase the risk of primary lung cancer, pneumonitis, and pulmonary fibrosis(5). Because most women with breast cancer are treated in the early stages, survival is important $(1,2)$.

Epidemiological studies have shown that the risks of secondary malignancies may be increased by radiotherapy or systemic therapy $(6,7)$. Primary lung cancer and heart disease are the most important long-term complications of breast cancer radiotherapy $(8,9)$.

Exposure to radiation in women undergoing radiotherapy may increase the risk of primary lung cancer. A metaanalysis of 75 randomized clinical trials of breast cancer radiotherapy showed that the risk of lung cancer due to radiotherapy increased by $11 \%$ (95\% confidence interval $(\mathrm{Cl}): 9 \%, 19 \%)(10,11)$.

In this study, the absolute potential risks of primary lung cancer following radiotherapy in women with primary breast cancer were evaluated based on the irradiated site, method, and treatment location. Therefore, the study aimed to assess the benefits and harms of breast cancer radiotherapy.

\section{Materials And Methods}

\section{Criteria for including studies}


Each of the PICOS elements was defined as follows: the patients were women with primary breast cancer $(P)$, the intervention was radiotherapy after breast cancer (I), the comparison group was patients who did not receive radiotherapy (C), and the outcome was primary lung, bronchus and trachea cancers (0), the studies included cohort studies without language restrictions (S). Risk ratio with 95\% confidence interval (95\% Cl) extracted from the studies. The exclusion criteria included the following: (a) studies that did not have a non-exposed group, (b) studies that did not mention the size of the exposed and non-exposed groups, (c) studies with sample size less than 50, (d) review articles, letters, and case reports.

\section{Search methods}

The following terms were searched: (lung malignancy or lung tumor or lung cancer or lung neoplasms) and (breast neoplasms or breast cancer) and (radiation therapy or radiation or radiotherapy) and (second primary). The main databases including MEDLINE, Web of Science, and Scopus were searched until March 2021.

\section{Data extraction}

Two authors (BZ \& MAR) extracted the data independently. The data file contains the following variables: first author, year of publication, country, outcome (lung, bronchus, and trachea cancers), effect size with its $95 \% \mathrm{Cl}$, sample size, language, study design, age, and follow-up time.

\section{The methodological quality}

The methodological quality assessment of the studies was based on the Newcastle-Ottawa Scale (NOS)(12). The quality of included studies was considered based on the following classification: low quality: 0 to 6 scores, high quality: 7 to 9 scores (13).

\section{Statistical analyses}

Association between breast cancer radiotherapy and risk of lung, bronchus, and trachea cancers was estimated by risk ratio (RR) and 95\% confidence interval. The significant level was less than 0.05 . The heterogeneity of included studies was measured by using the chi-square test and the $\mathrm{I}^{2}$ statistic. We performed analyses using review manager (version 5.4.1) and Stata software (version 16.0). A random random-effects model was used to estimate the average effects. Publication bias analysis was evaluated with Begg's and Egger's tests and the Trim and Fill method.

\section{Results}

\section{Literature search}

The PRISMA study selection process is described in Fig. 1. We collected a total of 992 references through searching the three databases PubMed, Web of Science, and Scopus. After removing the number of duplicate references and irrelevant articles, the number of remaining articles reached 15 (14-28).

\section{Studies characteristics}

This meta-analysis consisted of 15 articles; six of them were done in America, five in Europe, and four in Asia. Articles are from 1987 to 2018. In this study, two comparisons were made; in the first comparison, the risk of lung 
cancer after breast cancer radiotherapy compared with those who did not receive radiotherapy and in the second comparison, the risk of lung, bronchus, and trachea cancers after breast cancer radiotherapy compared with those who did not receive radiotherapy. The comparisons were reported in 10 and 5 studies, respectively. Generally, 1,640,247 women with primary breast cancer were enrolled in the studies, of which 937,151 had not received radiotherapy and the remaining 703,096 had received radiotherapy (Table 1 ).

\section{The methodological quality}

NOS checklist was used for evaluation of the quality of included studies. All articles were prospective or retrospective cohorts whose data was linked to the surveillance, epidemiology, and results (SEER) cohort. The NOS score for each article was 7-9. Therefore, in general, the quality of articles in this meta-analysis was high.

\section{Synthesis of results}

Based on Fig. 2, there was no significant relationship between lung cancer and breast cancer radiotherapy (9 studies; RR=0.95, 95\%Cl: 0.87-1.02, P=0.15, heterogeneity: $\left.\right|^{2}=46 \%$ ). Similarly, according to Fig. 3 , there was no significant relationship between lung, bronchus, and trachea cancers and breast cancer radiotherapy (4 studies; RR=0.98, 95\%Cl: 0.93-1.02, $P=0.32$, heterogeneity: I2=48\%).

\section{Sensitivity analysis}

There was high heterogeneity across studies investigating the relationship between lung, bronchus, and trachea cancers and breast cancer radiotherapy $\left(1^{2}=87 \%\right)$. Grantzau's study (17) was the source of the heterogeneity. After excluding this study, the heterogeneity reached $48 \%$ (Table 2). In lung cancer meta-analysis results, heterogeneity reached $46 \%$ after the removal of Huang's article(18).

\section{Publication bias}

There was no evidence of publication bias based on the results of the Begg test $(P=0.767)$. However, there was some evidence of publication bias based on the Egger test $(P=0.038)$. Based on the Trim and Fill method, the incorrect risk ratio was $0.99(95 \% \mathrm{Cl}$ : 0.83-1.18) and after adding two miss studies, the risk rate was equal to 0.93 (95\% Cl: 0.63-1.37) (Figure 4).

\section{Discussion}

The results of this study showed that there is no significant relationship between the risk of lung cancer as well as lung, bronchus, and trachea cancers and breast cancer radiotherapy.

The answer to the question of whether radiotherapy after breast cancer may increase the risk of lung cancer can be examined in two ways. In the first step, the fundamental question is to what extent is breast cancer alone can increase the risk of primary lung cancer? So, we referred to the common risk factors for lung cancer and breast cancer. Regardless of radiotherapy, it is necessary to mention to what extent lung and breast cancers shared common risk factors. Patients with prior colorectal, pancreatic, renal, and breast cancer are at significantly higher rates of non-small cell lung cancer specifically adenocarcinoma (29). Although the reasons are unclear, several factors seem to be effective such as biology and patient risk factors including smoking history and hormone 
replacement therapy during postmenopausal period (30). The overall standardized incidence rate of lung cancer after breast cancer is reported to be 4.88 (95\% Cl: 4.70-5.07) (29).

Furthermore, we examined the known risk factors for lung cancer that interact with radiotherapy. Even this interaction can occur with systemic therapy for breast cancer. One of these risk factors is smoking. Smoking increases the risk of lung cancer by up to 11 times in the general population. The risks of lung cancer after breast cancer radiotherapy are significant for smokers(11). Smoking cessation has had a significant effect even during radiation therapy $(31,32)$. According to Taylor et al., in a systematic literature review of lung and heart doses in breast cancer regimens, women who received overvoltage in previous years were at greater risk than other women $(\mathrm{RR}=1.57 ; 95 \% \mathrm{Cl}: 1.24-1.99)$. In this article, the risk of modern radiotherapy for incidence lung cancer after radiotherapy in patients with breast cancer for long-term continuing in smokers and non-smokers is estimated at $4 \%$ and $0.3 \%$, respectively(11). A meta-analysis conducted by Grantzau et al. included 11 studies involving 113,516 women exposed to radiotherapy and 203,957 women without exposure. They showed no significant increased risk of lung cancer among women who did not receive radiotherapy. Conversely, the risk was higher in women who received radiotherapy(33). The standardized incidence rate of lung cancer after 5 years exposure was 1.25 (95\% Cl: 1.05-1.40), after 10 years was 1.58 (95\% Cl: $1.21,2.05)$ and after 15 years was 1.91 (95\% Cl: $1.11-3.29$ ) (33). The results of this study were different from our results in many aspects including effect size, study duration, inclusion criteria.

One of the studies that were omitted in the sensitivity analysis is the study by Huang et al(18). Cox regression results show that the adjusted hazard ratio was 10.078 times higher in the radiation therapy group than the nonradiation therapy group. The frequency distribution of patients' stages in this study is not known. One specific characteristic of this study was using relatively aggressive computed tomography of the thorax, which is not routinely performed during follow-up of patients with early-stage. The high rate of lung cancer reported in this study may be attributed to the treatment approach of the study.

The results of a meta-analysis conducted by Aznar and et al. showed that lung exposure to breast cancer radiotherapy is very different in different countries and among various regimens. The extent of the irradiated region, using breathing adaptation, and using prone or lateral decubitus patient positioning or proton therapy can be the main determinants of the amount of exposure(34).

The main limitation of the study was the lack of access to predisposing factors such as smoking status, a dose of radiotherapy, and classification of patients based on their follow-up years.

\section{Conclusion}

Radiotherapy for breast cancer is not associated with an excess risk of lung cancer. Due to the limited number of studies, further research is required.

\section{Declarations}

\section{Authors' contributions}

JP and BZ conceived of and coordinated the study. BZ, and MAR searched the literature, extracted and analyzed the data, and drafted the manuscript. JP, BZ, and MAR interpreted the results, and drafted and revised the 
manuscript. All authors read and approved the final manuscript.

\section{Funding}

This work was supported by the Hamadan University of Medical Sciences, Hamadan, Iran which had no role in study design, data collection, analysis, interpretation, or writing of the report.

\section{Availability of data and materials}

Not applicable (The current study was performed based on published literature and no datasets were generated).

\section{Ethics approval and consent to participate}

This article does not contain any studies with human participants or animals performed by any of the authors.

\section{Consent for publication}

Not Applicable

\section{Competing interests}

The authors declare that they have no competing interests.

\section{References}

1. Group TC. Effect of radiotherapy after breast-conserving surgery on 10-year recurrence and 15-year breast cancer death: meta-analysis of individual patient data for 10,801 women in 17 randomised trials. Lancet. 2011;378(9804):1707-16.

2. McGale P, Taylor C, Correa C, Cutter D, Duane F, Ewertz M, et al. Effect of radiotherapy after mastectomy and axillary surgery on 10-year recurrence and 20-year breast cancer mortality: meta-analysis of individual patient data for 8135 women in 22 randomised trials. Lancet (London, England). 2014;383(9935).

3. Overgaard M, Jensen M-B, Overgaard J, Hansen PS, Rose C, Andersson M, et al. Postoperative radiotherapy in high-risk postmenopausal breast-cancer patients given adjuvant tamoxifen: Danish Breast Cancer Cooperative Group DBCG 82c randomised trial. The Lancet. 1999;353(9165):1641-8.

4. Clarke M, Collins R, Darby S, Davies C, Elphinstone P, Evans V, et al. Effects of radiotherapy and of differences in the extent of surgery for early breast cancer on local recurrence and 15-year survival: an overview of the randomised trials. Lancet. 2005;366(9503):2087-106.

5. Lind PA, Marks LB, Jamieson TA, Carter DL, Vredenburgh JJ, Folz RJ, et al. Predictors for pneumonitis during locoregional radiotherapy in high-risk patients with breast carcinoma treated with high-dose chemotherapy and stem-cell rescue. Cancer: Interdisciplinary International Journal of the American Cancer Society. 2002;94(11):2821-9.

6. De Angelis R, Sant M, Coleman MP, Francisci S, Baili P, Pierannunzio D, et al. Cancer survival in Europe 19992007 by country and age: results of EUROCARE-5-a population-based study. The lancet oncology. 2014;15(1):23-34. 
7. Vogelius IR, Bentzen SM. A literature-based meta-analysis of clinical risk factors for development of radiation induced pneumonitis. Acta oncologica. 2012;51(8):975-83.

8. Shaitelman SF, Howell RM, Smith BD. The Effects of Smoking on Late toxicity from breast radiation. Journal of clinical oncology: official journal of the American Society of Clinical Oncology. 2017;35(15):1633.

9. Tubiana M. Can we reduce the incidence of second primary malignancies occurring after radiotherapy? A critical review. Radiother Oncol. 2009;91(1):4-15.

10. Evans H, Lewis C, Robinson D, Bell C, Møller H, Hodgson S. Incidence of multiple primary cancers in a cohort of women diagnosed with breast cancer in southeast England. British journal of cancer. 2001;84(3):435-40.

11. Taylor C, Correa C, Duane FK, Aznar MC, Anderson SJ, Bergh J, et al. Estimating the risks of breast cancer radiotherapy: evidence from modern radiation doses to the lungs and heart and from previous randomized trials. J Clin Oncol. 2017;35(15):1641.

12. Wells GA, Shea B, O'Connell Da, Peterson J, Welch V, Losos M, et al. The Newcastle-Ottawa Scale (NOS) for assessing the quality of nonrandomised studies in meta-analyses. Oxford; 2000.

13. Poorolajal J, Jenabi E, Masoumi SZ. Body mass index effects on risk of ovarian cancer: a meta-analysis. Asian Pac J Cancer Prev. 2014;15(18):7665-71.

14. Andersson M, Storm HH, Mouridsen HT. Incidence of new primary cancers after adjuvant tamoxifen therapy and radiotherapy for early breast cancer. JNCl: Journal of the National Cancer Institute. 1991;83(14):1013-7.

15. Burt LM, Ying J, Poppe MM, Suneja G, Gaffney DK. Risk of secondary malignancies after radiation therapy for breast cancer: Comprehensive results. Breast. 2017;35:122-9.

16. De Gonzalez AB, Curtis R, Gilbert E, Berg C, Smith S, Stovall M, et al. Second solid cancers after radiotherapy for breast cancer in SEER cancer registries. British journal of cancer. 2010;102(1):220-6.

17. Grantzau T, Mellemkjaer L, Overgaard J. Second primary cancers after adjuvant radiotherapy in early breast cancer patients: a national population based study under the Danish Breast Cancer Cooperative Group (DBCG). Radiother Oncol. 2013;106(1):42-9.

18. Huang Y-J, Huang T-W, Lin F-H, Chung C-H, Tsao C-H, Chien W-C. Radiation therapy for invasive breast cancer increases the risk of second primary lung cancer: a nationwide population-based cohort analysis. Journal of Thoracic Oncology. 2017;12(5):782-90.

19. Kamigaki Y, Kawakami K. Risk of second cancer after initial treatment of breast cancer: An Osaka Cancer Registry Database study. Oncology letters. 2011;2(5):963-73.

20. Lavey RS, Eby NL, Prosnitz LR. Impact of radiation therapy and/or chemotherapy on the risk for a second malignancy after breast cancer. Cancer. 1990;66(5):874-81.

21. Levi F, Randimbison L, Te VC, La Vecchia C. Cancer risk after radiotherapy for breast cancer. Br J Cancer. 2006;95(3):390-2.

22. Murakami R, Hiyama T, Hanai A, Fujimoto I. Second primary cancers following female breast cancer in Osaka, Japan-a population-based cohort study. Jpn J Clin Oncol. 1987;17(4):293-302.

23. Neugut Al, Lee WC, Murray T, Robinson E, Karwoski K, Kutcher GJ. Lung cancer after radiation therapy for breast cancer. Cancer. 1993;71(10):3054-7.

24. Roychoudhuri R, Evans H, Robinson D, Moller H. Radiation-induced malignancies following radiotherapy for breast cancer. Br J Cancer. 2004;91(5):868-72. 
25. Rubino C, de Vathaire F, Diallo I, Shamsaldin A, Lê MG. Increased risk of second cancers following breast cancer: role of the initial treatment. Breast cancer research treatment. 2000;61(3):183-95.

26. Travis LB, Curtis RE, Inskip PD, Hankey BF. Re. Lung cancer risk and radiation dose among women treated for breast cancer. J Natl Cancer Inst. 1995;87(1):60-1.

27. Wang R, Yin Z, Liu L, Gao W, Li W, Shu Y, et al. Second Primary Lung Cancer After Breast Cancer: A Population-Based Study of 6,269 Women. Front Oncol. 2018;8:427.

28. Withrow DR, Morton LM, Curtis RE, Schonfeld SJ, Berrington de Gonzalez A. Radiotherapy for ductal carcinoma in situ and risk of second non-breast cancers. Breast Cancer Res Treat. 2017;166(1):299-306.

29. Wu GX, Nelson RA, Kim JY, Raz DJ. Non-Small Cell Lung Cancer as a Second Primary Among Patients With Previous Malignancy: Who Is at Risk? Clin Lung Cancer. 2017;18(5):543-50. e3.

30. Baik CS, Strauss GM, Speizer FE, Feskanich D. Reproductive factors, hormone use, and risk for lung cancer in postmenopausal women, the Nurses' Health Study. Cancer Epidemiology Prevention Biomarkers. 2010;19(10):2525-33.

31. Pirie K, Peto R, Reeves GK, Green J, Beral V, Collaborators MWS. The 21st century hazards of smoking and benefits of stopping: a prospective study of one million women in the UK. The Lancet. 2013;381(9861):13341.

32. Thun MJ, Carter BD, Feskanich D, Freedman ND, Prentice R, Lopez AD, et al. 50-year trends in smoking-related mortality in the United States. N engl J med. 2013;368:351-64.

33. Grantzau T, Overgaard J. Risk of second non-breast cancer among patients treated with and without postoperative radiotherapy for primary breast cancer: a systematic review and meta-analysis of populationbased studies including 522,739 patients. Radiother Oncol. 2016;121(3):402-13.

34. Aznar MC, Duane FK, Darby SC, Wang Z, Taylor CW. Exposure of the lungs in breast cancer radiotherapy: a systematic review of lung doses published 2010-2015. Radiother Oncol. 2018;126(1):148-54.

\section{Tables}

Table1: Summary of articles in the meta-analysis 


\begin{tabular}{|c|c|c|c|c|c|c|c|}
\hline First author, year & Country & Outcome & $\begin{array}{c}\text { Effect } \\
\text { size }\end{array}$ & $\begin{array}{c}\text { Sample } \\
\text { size }\end{array}$ & $\begin{array}{c}\text { Risk } \\
\text { Ratio } \\
(95 \% \mathrm{CI})\end{array}$ & Quality & $\begin{array}{c}\text { Follow- } \\
\text { up } \\
\text { time }\end{array}$ \\
\hline Murakami (22), 1987 & Japan & lung cancer & $\begin{array}{l}\text { Risk } \\
\text { Ratio }\end{array}$ & 8671 & $\begin{array}{c}0.46 \\
{[0.13-} \\
1.63]\end{array}$ & high & 17 \\
\hline Lavey $(20), 1990$ & USA & lung cancer & $\begin{array}{l}\text { Risk } \\
\text { Ratio }\end{array}$ & 366 & $\begin{array}{c}2.26 \\
{[0.21-} \\
24.76]\end{array}$ & high & 11 \\
\hline Anderson ${ }^{(14)}, 1991$ & Denmark & $\begin{array}{c}\text { Respiratory } \\
\text { system }\end{array}$ & $\begin{array}{l}\text { Risk } \\
\text { Ratio }\end{array}$ & 2674 & $\begin{array}{c}0.65 \\
{[0.18-} \\
2.36]\end{array}$ & high & 5 \\
\hline Travis ${ }^{(26)}, 1995$ & USA & lung cancer & $\begin{array}{l}\text { Risk } \\
\text { Ratio }\end{array}$ & 27387 & $\begin{array}{c}0.87 \\
{[0.76-} \\
1.00]\end{array}$ & high & 18 \\
\hline Rubino $(25), 2000$ & French & $\begin{array}{l}\text { Lung, } \\
\text { bronchus } \\
\text { and } \\
\text { trachea }\end{array}$ & $\begin{array}{l}\text { Risk } \\
\text { Ratio }\end{array}$ & 3629 & $\begin{array}{c}4.89 \\
{[0.27-} \\
88.50]\end{array}$ & high & 30 \\
\hline Roychoudhuri $(24), 2004$ & UK & lung cancer & $\begin{array}{c}\text { Risk } \\
\text { Ratio }\end{array}$ & 64782 & $\begin{array}{c}1.10 \\
{[0.92-} \\
1.31]\end{array}$ & high & 39 \\
\hline Levi $(21), 2006$ & Switzerland & lung cancer & $\begin{array}{l}\text { Risk } \\
\text { Ratio }\end{array}$ & 6119 & $\begin{array}{c}1.91 \\
{[0.90-} \\
4.07]\end{array}$ & high & 24 \\
\hline Grantzau (17),2013 & Denmark & $\begin{array}{l}\text { Lung, } \\
\text { bronchus } \\
\text { and } \\
\text { trachea }\end{array}$ & $\begin{array}{l}\text { Risk } \\
\text { Ratio }\end{array}$ & 46176 & $\begin{array}{c}0.60 \\
{[0.50-} \\
0.73]\end{array}$ & high & 25 \\
\hline Withrow ${ }^{(28)}, 2017$ & USA & $\begin{array}{l}\text { Lung, } \\
\text { bronchus } \\
\text { and } \\
\text { trachea }\end{array}$ & $\begin{array}{l}\text { Risk } \\
\text { Ratio }\end{array}$ & 52556 & $\begin{array}{c}1.18 \\
{[0.98-} \\
1.41]\end{array}$ & high & 20 \\
\hline Burt $(15), 2017$ & USA & $\begin{array}{c}\text { Respiratory } \\
\text { system }\end{array}$ & $\begin{array}{l}\text { Risk } \\
\text { Ratio }\end{array}$ & 374993 & $\begin{array}{c}0.96 \\
{[0.91-} \\
1.01]\end{array}$ & high & 35 \\
\hline Rong Wang $(27), 2018$ & China & lung cancer & $\begin{array}{l}\text { Risk } \\
\text { Ratio }\end{array}$ & 620429 & $\begin{array}{c}0.98 \\
{[0.93-} \\
1.03]\end{array}$ & high & 16 \\
\hline De Gonzalez (16), 2009 & USA & lung cancer & $\begin{array}{l}\text { Risk } \\
\text { Ratio }\end{array}$ & 182057 & $\begin{array}{c}0.95 \\
{[0.88-} \\
1.04]\end{array}$ & high & 32 \\
\hline Kamigaki (19), 2011 & Japan & lung cancer & $\begin{array}{l}\text { Risk } \\
\text { Ratio }\end{array}$ & 33043 & $\begin{array}{c}0.88 \\
{[0.64-} \\
1.22]\end{array}$ & high & 28 \\
\hline Neugut (23), 1993 & USA & lung cancer & $\begin{array}{l}\text { Risk } \\
\text { Ratio }\end{array}$ & 54946 & $\begin{array}{c}0.77 \\
{[0.63-} \\
0.94]\end{array}$ & high & 13 \\
\hline Huang (18), 2017 & Taiwan & lung cancer & Risk & 7277 & 9.82 & high & 10 \\
\hline
\end{tabular}




\begin{tabular}{l|l|l|l|l|l|} 
& Ratio & & & \\
26.53 & & \\
\hline
\end{tabular}

Table2: Results before and after sensitivity analysis in terms of each outcome

\begin{tabular}{|c|c|c|c|c|c|}
\hline Jutcome & Studies & $\mathrm{I}^{2}$ & $\begin{array}{c}\text { Number of } \\
\text { RT }\end{array}$ & $\begin{array}{c}\text { Number of } \\
\text { NRT }\end{array}$ & $\begin{array}{c}\text { Effect size } \\
95 \% \mathrm{CI}\end{array}$ \\
\hline \multicolumn{6}{|l|}{$\begin{array}{l}\text { _ung, bronchus, and trachea } \\
\text { zancers }\end{array}$} \\
\hline 3efore sensitivity analysis & 5 & $87 \%$ & 206037 & 273991 & $\begin{array}{l}0.94(0.90- \\
0.99)\end{array}$ \\
\hline After sensitivity analysis & 4 & $48 \%$ & 182410 & 251442 & $\begin{array}{l}0.98(0.93- \\
1.02)\end{array}$ \\
\hline \multicolumn{6}{|l|}{-ung cancer } \\
\hline 3efore sensitivity analysis & 10 & $75 \%$ & 497059 & 663160 & $\begin{array}{l}0.97(0.86- \\
1.10)\end{array}$ \\
\hline After sensitivity analysis & 9 & $46 \%$ & 491491 & 661451 & $\begin{array}{l}0.95(0.87- \\
1.02)\end{array}$ \\
\hline
\end{tabular}

\section{Figures}




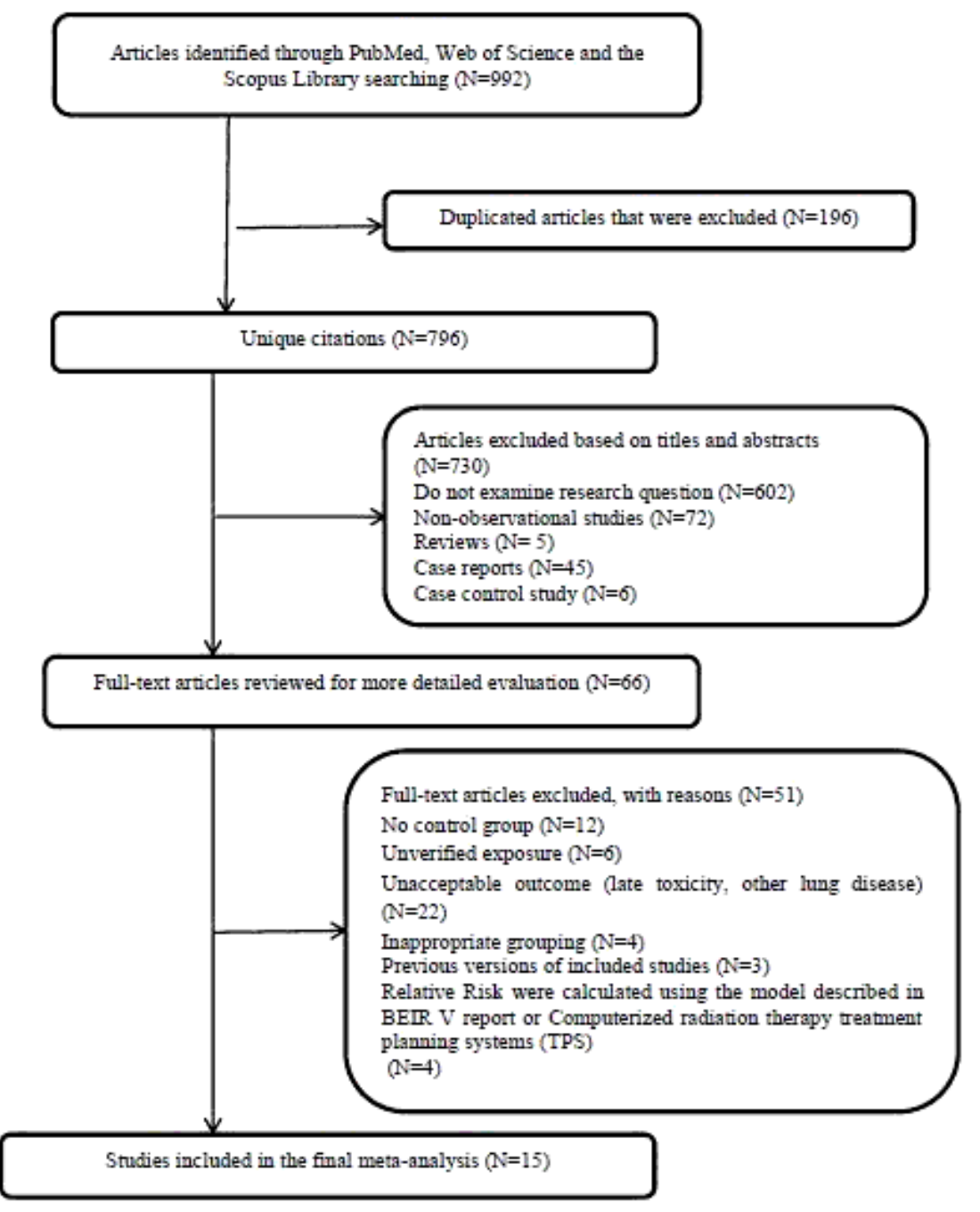

\section{Figure 1}

PRISMA flow chart showing the study selection process

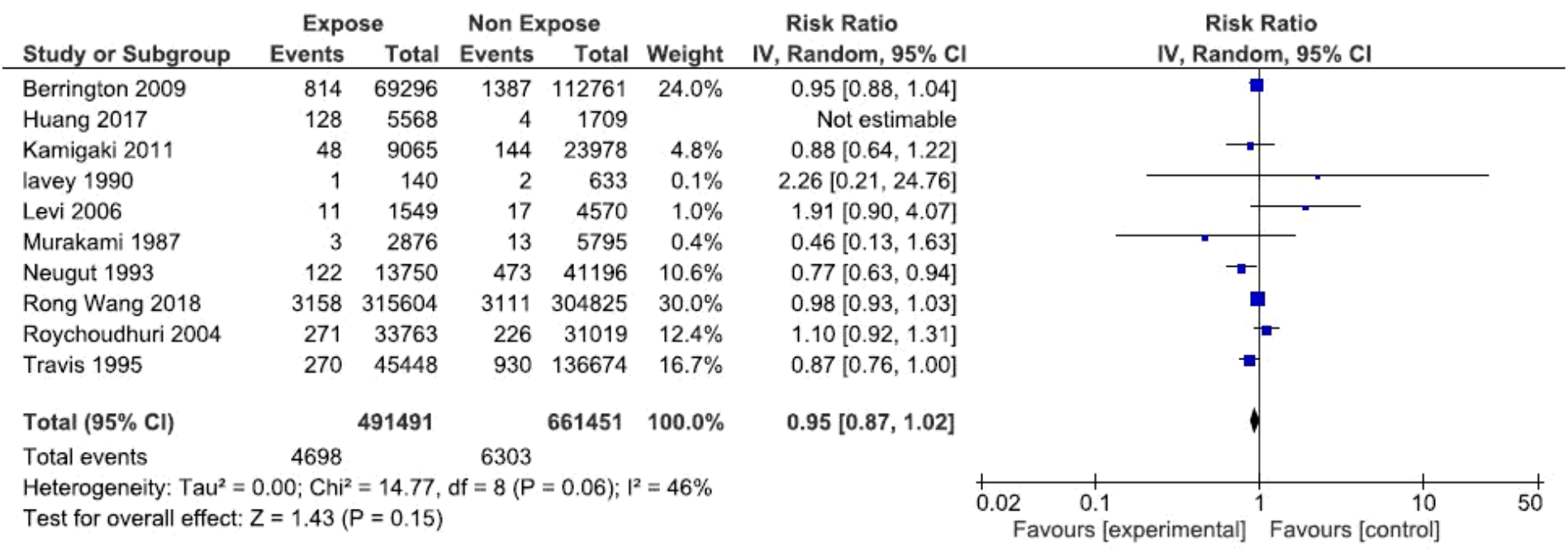

Figure 2 
Forest plots of meta-analysis of the included studies on the association between radiotherapy for breast cancer and primary lung cancer.

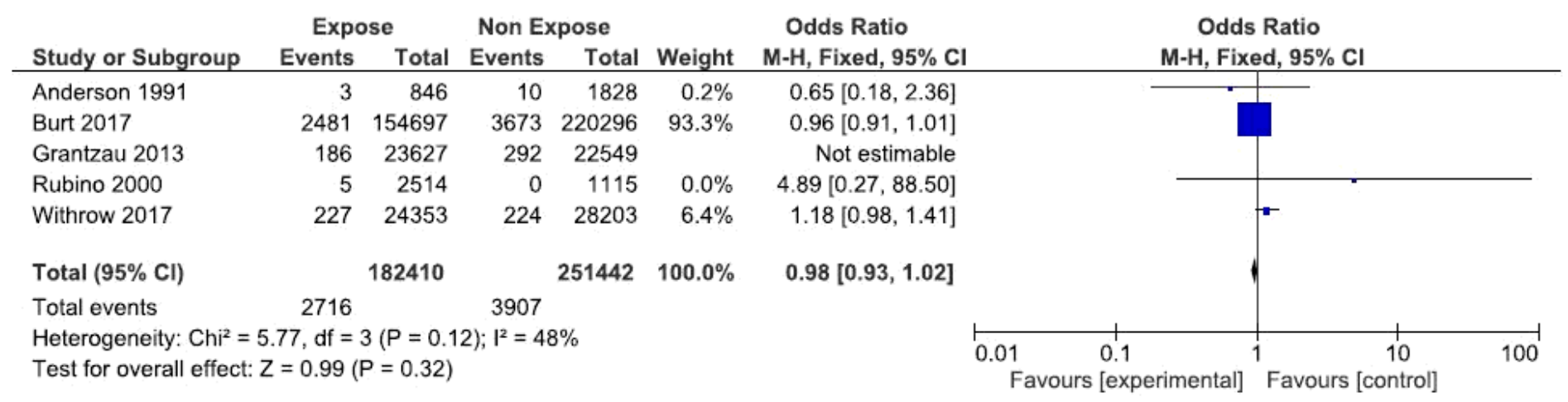

\section{Figure 3}

Forest plots of meta-analysis of the included studies on the association between radiotherapy for breast cancer and primary, lung, bronchus, and trachea cancers

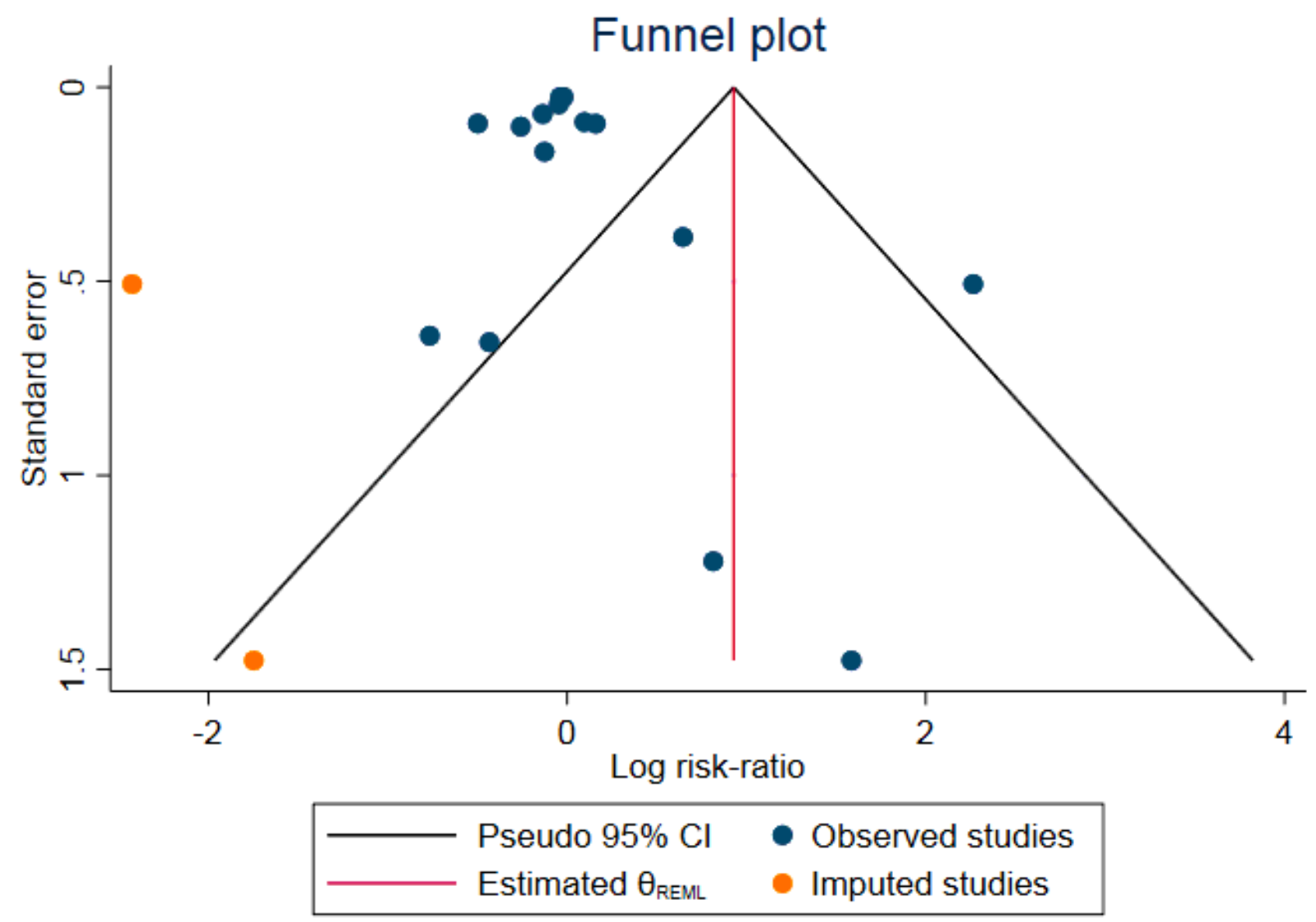

\section{Figure 4}

Trim \& Fill analysis estimating the number of possible missing studies for the association between radiotherapy for breast cancer and primary, lung, bronchus, and trachea cancers 